\title{
Characterization of Struvite Produced by an Algal Associated Agarolytic Bacterium Exiguobacterium aestuarii St. SR 101
}

\section{Sheeja Leela ${ }^{1}$, Jayappriyan Kothilmozhian Ranishree ${ }^{2 *}$, Ramesh Kannan Perumal ${ }^{2}$ and Rengasamy Ramasamy ${ }^{2}$}

${ }^{1}$ Shrimathi Devkunvar Nanalal Bhatt Vaishnav College for Women, Chromepet, Chennai - 600044 , India. ${ }^{2}$ Centre for Advanced Studies in Botany, University of Madras, Gundy Campus, Chennai - 600 025, India.

\begin{abstract}
Biomineralization phenomenon of bacteria proved to have various biotechnological and environmental applications. Production of magnesium ammonium phosphate (struvite) crystals by the agarolytic bacterium Exiguobacterium aestuarii St. SR 101 isolated from red seaweed, Gracilaria corticata was reported for the first time in the present study. Struvite crystallization occurred in the agar culture medium in the presence of the bacterium. Crystal nucleation and growth occurred apparently as a consequence of the localized ion supersaturation, produced by the microbial metabolites and also by the microbial supply of heterogeneous nuclei resulted in crystallization. The crystals were visible between 10 to 15 days after inoculation. The crystal structure of the struvite characterized by optical microscopy, IR spectroscopy, thermogravimetry, powder X-ray diffractometry, and single crystal X-ray diffractometry. The orthorhombic crystal is with the space group Pmn2 and unit-cell parameters $a=$ $6.9447 \AA$, $b=6.1329 \AA$, $c=11.2026 \AA$. Exiguobacterium aestuarii St. SR 101 showed to have the capacity of producing struvite based fertilizer by bioremediation of industrial phosphate wastes.
\end{abstract}

Keywords: Exiguobacterium aestuarii; biomineralization; struvite; agarolytic; $\mathrm{X}$-ray diffractometry.

*Correspondence: jayapriyan@gmail.com

(Received: 02 April 2019; accepted: 20 May 2019)

Citation: Sheeja Leela, Jayappriyan Kothilmozhian Ranishree, Ramesh Kannan Perumal and Rengasamy Ramasamy, Characterization of Struvite Produced By an Algal Associated Agarolytic Bacterium Exiguobacterium aestuarii St. SR 101, J Pure Appl Microbiol., 2019; 13(2): 1227-1234. doi: 10.22207/JPAM.13.2.64

C The Author(s) 2019. Open Access. This article is distributed under the terms of the Creative Commons Attribution 4.0 International License which permits unrestricted use, sharing, distribution, and reproduction in any medium, provided you give appropriate credit to the original author(s) and the source, provide a link to the Creative Commons license, and indicate if changes were made. 


\section{INTRODUCTION}

Biomineralization refers to a process which involves the formation of minerals. Bacterial activity related to the precipitation of a wide range of minerals including carbonates, oxides, phosphates, sulfides, and silicates ${ }^{1}$. The extracellular precipitation processes of mineral compounds by bacteria are due to metabolic activity that favors the physicochemical conditions resulting in the formation of biominerals. In natural biomineralization, bacterial metabolic enzymes can generate supersaturated conditions. Moreover, it is an established and experimentally proven fact that bacterial structures participate in the extra or intracellular accumulation of inorganic material ${ }^{2,3}$. The significant role of bacterial biomineralization is to deliver structures that serve as substrates for heterogeneous crystal nucleation (with lower energy barriers than homogeneous nucleation) and stereochemical arrangements of the mineral components. Therefore, providing the necessary elements and conditions and the mere existence of bacteria would themselves suffice for biomineralization processes ${ }^{4,5}$. Interaction between soil bacteria and minerals reported having many bio-technological and environmental applications $s^{6,7}$.

Among phosphate containing biominerals, struvite, $\mathrm{MgNH}_{4} \mathrm{PO}_{4} \cdot 6 \mathrm{H}_{2} \mathrm{O}$, has attracted considerable attention because of its common occurrence in widely diverse environments, such as bat droppings, decomposed foods, a part of biofilms that develop inside the pipelines in water treatment facilities. Crystallization of nitrogen and phosphorous in the form of struvite has been successfully used for nutrient removal and for obtaining a valuable fertilizer. The mineral struvite was named already in 1845 after the Russian Mineralogist, Heinrich Von Struve. According to Robinson's proposals, struvite production could be the consequence of a combination of ammonium ions formed by the metabolism of nitrogenous compounds with phosphate and magnesium present in the environment ${ }^{8}$. Several soil-inhabiting genera like Azotobacter, Bacillus, Myxococcus, and Pseudomonas have been studied for their potential to form struvite ${ }^{2}$. Medical reports reveal that struvite is well known from the bladder and urinary concretions.

Due to its importance in many fields of interest, it was thoroughly investigated by mineralogists, chemists, physicians, and environmentalists, who studied it from different points of view and described many physical and chemical properties. The crystal structure of struvite by Whitaker and Jeffery belongs to the orthorhombic space group Pmn2 ${ }_{1}$ with two molecules in a unit cell ${ }^{9}$. There are many structural similarities between struvite type materials, which have been of great interest because of their broad and important biological, agricultural and industrial implications ${ }^{10,11,12}$. For example, $\mathrm{Mg}^{2+}$ cations in these compounds are all coordinated octahedrally by six $\mathrm{H}_{2} \mathrm{O}$ molecules whose $\mathrm{H}$ atoms are strongly bonded to oxygen atoms in $\left(\mathrm{PO}_{4}\right)^{3-}$ groups. $\mathrm{No}_{2} \mathrm{O}$ molecules are shared between $\mathrm{Mg}\left(\mathrm{H}_{2} \mathrm{O}\right)_{6}$ octahedra. Another common feature among the struvite type phosphate compounds is the face-sharing between $\mathrm{PO}_{4}$ tetrahedra and $\mathrm{Mg}\left(\mathrm{H}_{2} \mathrm{O}\right)_{6}$ octahedra through hydrogen bonding, although the number of shared faces may vary from structure to structure. The present study reported a phosphate containing, biologically formed crystal, struvite, which has the chemical composition $\mathrm{MgNH}_{4} \mathrm{PO}_{4} \cdot 6 \mathrm{H}_{2} \mathrm{O}$, from the agarolytic bacterium $E$. aestuarii St. SR 101 isolated from the red seaweed, G. corticata.

\section{MATERIALS AND METHODS}

Isolation and identification of the bacterium

The agarolytic bacterium $E$. aestuarii St. SR 101, isolated from red seaweed G. corticata collected from Kovalam coast, near Chennai, India. The homogenized algal sample inoculated in medium containing $1.5 \%$ agar, $0.05 \%$ yeast extract, $0.5 \%$ peptone, $3 \% \mathrm{NaCl}, 0.06 \% \mathrm{NaH}_{2} \mathrm{PO}_{4}$, and $0.01 \% \mathrm{CaCl}_{2}$ at room temperature $\left(24-27^{\circ} \mathrm{C}\right)$ and under static condition. Within 3 days, the agar medium became liquefied due to the production of agarolytic enzyme agarase. After 10 to 15 days crystals were present in the medium. The crystals were harvested by washing thoroughly using double distilled water, air dried and stored in glass vials. The isolated bacterial stain characterized as described previously ${ }^{6,13}$.

\section{Effect of four different nutrients on the production} of struvite

Four different ingredients of the basal medium viz., Peptone, yeast extract, $\mathrm{NaH}_{2} \mathrm{PO}_{4}$ and $\mathrm{MgSO}_{4}$ were amended at seven different 
concentrations (Peptone- 0.4, 0.5, 0.6, 0.7, 0.8, $0.9,1 \%$; Yeast extract $-0.04,0.05,0.06,0.07,0.08$, $0.09,0.1 \% ; \mathrm{NaH}_{2} \mathrm{PO}_{4}-0.05,0.06,0.07,0.08,0.09$, $0.1 \%$ and $\mathrm{MgSO}_{4} 0.4,0.5,0.6,0.7,0.8,0.9$ and $1 \%)$, and the bacterium was inoculated separately under respective concentrations in the medium without $\mathrm{CaCl}_{2}, \mathrm{NaH}_{2} \mathrm{PO}_{4}$ and $\mathrm{MgSO}_{4}$. The flasks were periodically observed for the presence of crystals, under room temperature at static condition. The crystals were collected after 15 days and transferred to distilled water and washed free of impurities. They were air dried, and the dry weight was recorded. Uninoculated culture medium was considered as negative control.

\section{Characterization of crystals}

The crystals obtained from the culture medium were ground into a fine powder and analyzed under powder X-ray diffraction using an $X^{\prime}$ pert PRO (PAN analytical) diffractometer with nickel-filtered CuK radiation in the $2 \theta$ range $5-80^{\circ}$ with scan step size $0.02^{\circ} \mathrm{s}$. Fourier transform infrared of the crystals was recorded in the range of $400-4000 \mathrm{~cm}^{-1}$ using Perkin - Elmer RX1 FT-IR spectrophotometer in the form of solids dispersed in $\mathrm{KBr}$ pellets. Thermal analysis was carried out using SDT Q600 V8.0 Build 95 between $0^{\circ} \mathrm{C}$ and $900^{\circ} \mathrm{C}$ by thermal gravimetric analysis. Based on the optical examination, a prismatic crystal of $0.3 \mathrm{x}$ $0.2 \times 0.2 \mathrm{~mm}$ was selected and mounted on a CAD4 Enraf-Nonius single crystal X-ray diffractometer equipped with graphite mono-chromatized MoK $\alpha$ radiation. A hemisphere of three dimensional X-ray diffraction data was collected with frame widths of $0.3^{\circ}$.

Table 1. Effect of different nutrients on the yield of crystals.

\begin{tabular}{lcccc}
\hline $\begin{array}{l}\text { Peptone } \\
(\%)\end{array}$ & $\begin{array}{c}\text { Yeast } \\
(\%)\end{array}$ & $\begin{array}{c}\mathrm{NaH}_{2} \mathrm{PO}_{4} \\
(\%)\end{array}$ & $\begin{array}{c}\mathrm{MgSO}_{4} \\
(\%)\end{array}$ & $\begin{array}{c}\text { Yield (mg)/ } \\
100 \mathrm{~L}\end{array}$ \\
\hline 0.4 & 0.04 & 0.05 & 0.4 & 16.0 \\
$0.5(\mathrm{C})$ & $0.05(\mathrm{C})$ & $0.06(\mathrm{C})$ & $0.5(\mathrm{C})$ & $30.9(\mathrm{C})$ \\
0.6 & 0.06 & 0.07 & 0.6 & 54.5 \\
0.7 & 0.07 & 0.08 & 0.7 & 56.5 \\
0.8 & 0.08 & 0.09 & 0.8 & 97.0 \\
0.9 & 0.09 & 0.10 & 0.9 & 125.9 \\
1.0 & 0.10 & 0.20 & 1.0 & 144.9 \\
\hline
\end{tabular}

(C) - Positive Control

\section{RESULTS AND DISCUSSION}

\section{Culture conditions of $E$. aestuarii}

The bacterium E. aestuarii St. SR 101 grown in different cultural conditions concerning the yield of struvite revealed the following observations. The amount of struvite produced by the bacterium was directly proportional to the concentration of the ingredients tested. Increasing concentrations of the combination of peptone, yeast extract, $\mathrm{NaH}_{2} \mathrm{PO}_{4}$, and $\mathrm{MgSO}_{4}$ increased the yield of struvite under the static condition at room temperature. The organism grown in the medium contained $0.1 \%$ yeast extract, $1.0 \%$ peptone, $3.0 \%$ $\mathrm{NaCl}, 0.2 \% \mathrm{NaH}_{2} \mathrm{PO}_{4}$, and $1.0 \% \mathrm{MgSO}_{4}$ showed a maximum of $145.0 \mathrm{mg} / 100 \mathrm{~mL}$, which was 5 fold more than positive control $(30 \mathrm{mg} / 100 \mathrm{~mL}$ ) (Table 1). In the present study, no precipitation occurred in the negative control. These results are similar to those observed on moderately halophilic bacteria ${ }^{14,15}$.

The present bacterium did not produce struvite when the medium devoid of any one of the ingredients viz., $\mathrm{CaCl}_{2}, \mathrm{NaH}_{2} \mathrm{PO}_{4}$ and $\mathrm{MgSO}_{4}$. Thus, these inorganic chemicals showed great influence on mineral precipitation ${ }^{5}$. The metabolic activity of bacteria made a change in $\mathrm{pH}$, ionic strength and ionic makeup of the media which modify their minerogenetic tendency and also affect cell surface charges which in turn modify the proportions of $\mathrm{Ca}^{2+}$ and $\mathrm{Mg}^{2+}$ captured by the cell surface ${ }^{16,17}$. According to Rivadeneyra et al. struvite formation by bacteria involves the adsorption of $\mathrm{Mg}^{2+}$ and $\mathrm{PO}_{4}^{3-}$ ions, which in conjugation with the release of $\mathrm{NH}_{4}^{+}$ions may form microenvironments suitable for precipitation of this mineral ${ }^{18}$. In the present study, crystal formation occurs in the medium supplemented with $\mathrm{CaCl}_{2}, \mathrm{NaH}_{2} \mathrm{PO}_{4}$, and $\mathrm{MgSO}_{4}$. Phosphate and magnesium are the major ingredients, whereas ammonium is believed to be released from the cells during incubation. The medium supplemented with organic nitrogen sources like peptone and yeast extract help the metabolic formation of ammonium. The light, alkaline $\mathrm{pH}$ of the medium 7.5, favors the conditions for biomineralization for the crystallization of struvite. Micrographic crystalline structure struvite produced by $E$. aestuarii illustrated in Fig. 1.

Solubility

The struvite crystals were soluble up to 


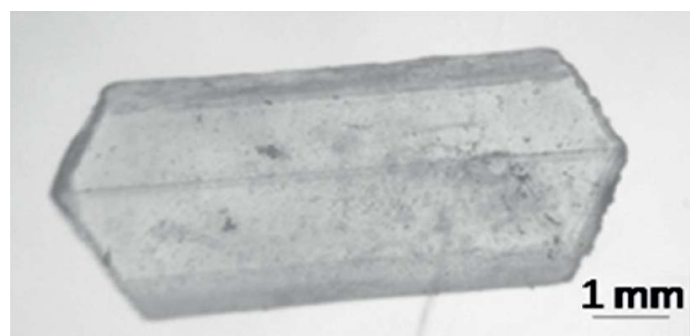

Fig. 1. Optical micrograph is showing the crystal structure of struvite obtained from E. aestuarii St. SR 101.

$\mathrm{pH}$ 5.4, and a further increase in $\mathrm{pH}$ decreased the solubility. The crystals were not soluble in neutral and alkaline $\mathrm{pH}$. Struvite solubility was determined chiefly by the concentration of magnesium, ammonium and phosphate and $\mathrm{pH}$ of the solutions ${ }^{19}$. In the present study struvite crystals formed from E. aestuarii were soluble in acidic $\mathrm{pH}$, and as the $\mathrm{pH}$ increased the solubility decreased. It was soluble in $0.1 \mathrm{M}$ citrate buffer pH from 3.0 to 5.4 .

\section{Thermal Analysis}

Thermogravimetric analysis of the crystals was carried out between room temperature and $1000^{\circ} \mathrm{C}$ in the nitrogen atmosphere. The thermogram obtained is presented in Fig. 2 . The thermal decomposition of struvite formed from
E. aestuarii started at $60^{\circ} \mathrm{C}$ and ended at $180^{\circ} \mathrm{C}$ with the peak temperature at $121^{\circ} \mathrm{C}$ resulted in a weight loss of $51.02 \%$ which corresponded to six molecules of water and one molecule of ammonia ${ }^{20}$. The resulting $\mathrm{MgPO}_{4}$ seems to be thermally stable up to $900^{\circ} \mathrm{C}$. Since the loss of water occurs at a specific temperature, they are presumed to escape from the crystal lattice rather than from the crystal surface. Powder X-ray diffraction pattern of struvite crystals (Fig. 3 ) has given the evidence of elements viz., $\mathrm{Mg}, \mathrm{P}, \mathrm{N}, \mathrm{O}$ and $\mathrm{H}$. The lattice parameters were evaluated and found to be $a=6.955, b=6.142$. and $c=11.218$, which are in conformity of the single crystal values. The powdered XRD pattern of struvite crystals in the present study matched very well with that of the published pattern for struvite (JCPDS file No. 77-2303).

\section{IR Spectroscopic analysis}

Water molecules possess three modes of structural vibrations $v_{1}, v_{2}, v_{3}$. All these modes are infrared active and occur at $3652\left(v_{1}\right), 1595\left(v_{2}\right)$ and $3765\left(\mathrm{v}_{3}\right) \mathrm{cm}^{-1}$ in the vapor phase. They show shifts in liquid and solid phases. In general, their positions in the liquid phase are at 3219, 1645 and 3405 phase are 3219, 1645 and $3405 \mathrm{~cm}^{-1}$ where as in solid phase they are 3200, 1640 and $3400 \mathrm{~cm}^{-1}$ where $\mathrm{aacm}^{-1}$ whereas in solid phase

USC-IGA

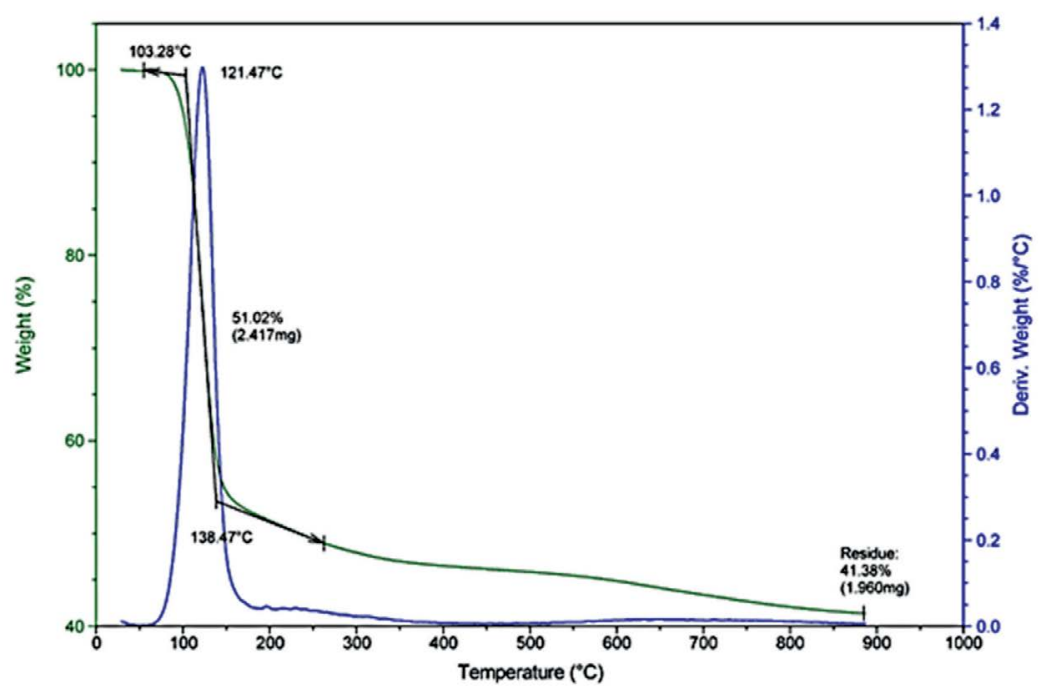

Fig. 2 Thermography of struvite crystals in the nitrogen atmosphere, showing a thermogravimetric peak at $121.47^{\circ} \mathrm{C}$. 


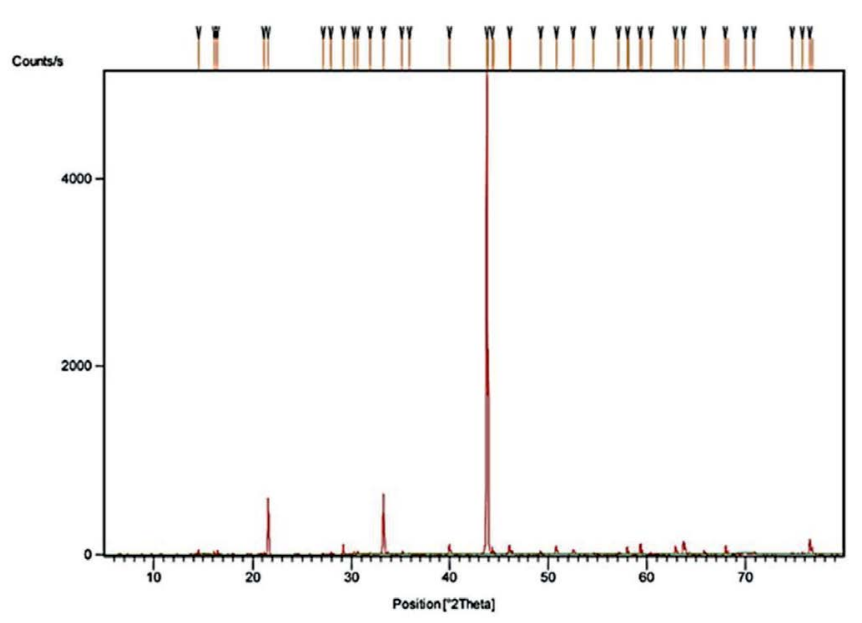

Fig. 3. X-ray diffraction powder pattern of struvite crystal.

they are at 3200,1640 and $3400 \mathrm{~cm}^{-1}$ respectively. Such shifts are characteristics of hydrogen bonding in liquid and solid phases. The IR spectrum of the struvite obtained from $E$. aestuarii exhibits three bands characteristics of a water molecule at 1659, 3204 and $2924 \mathrm{~cm}^{-1}$ (Fig. 4). They are attributed to the structural vibrations $v_{2}$ (bending mode), $v_{1}$ (Symmetric stretch) and $v_{3}$ (asymmetric stretch) respectively. The band of the struvite obtained from $E$. aestuarii culture medium observed at $750 \mathrm{~cm}^{-1}$ is assigned to water-water $\mathrm{H}$-bonding ${ }^{21}$. The bands appeared at 457, 573 and $1005 \mathrm{~cm}^{-1}$ assigned to different modes of vibrations of $\mathrm{PO}_{4}$. The band at 1447 attributed to $\mathrm{NH}_{3}$. Therefore, the presence of $\mathrm{PO}_{4}, \mathrm{NH}_{3}$, and water in the struvite was confirmed.

\section{Single Crystal X-ray Diffraction studies}

Struvite crystal of size $0.3 \times 0.2 \times 0.2 \mathrm{~mm}$ was taken for data collection. The intensity data were collected using SMART CCD diffractometer $(\lambda=0.7103)$ at the Indian Institute of Technology, Chennai. The data collection was concealed over a hemisphere of reciprocal space by a combination of three sets of exposures and each set had a different $\theta$ angle $\left(0^{\circ}, 88^{\circ}\right.$, and $\left.180^{\circ}\right)$ for the crystal and each exposure of 30 seconds covered $0.3^{\circ}$ in $\omega$. The crystal to detector distance was $4 \mathrm{~cm}$, and the detector swing angle was $-35^{\circ}$. Crystal decay was monitored by repeating 30 frames at the end of data collection (Table 2 ).

The intensities were collected with $\theta$ range from 3.32 to $28.28^{\circ}$ at $293 \mathrm{~K}$. The values of

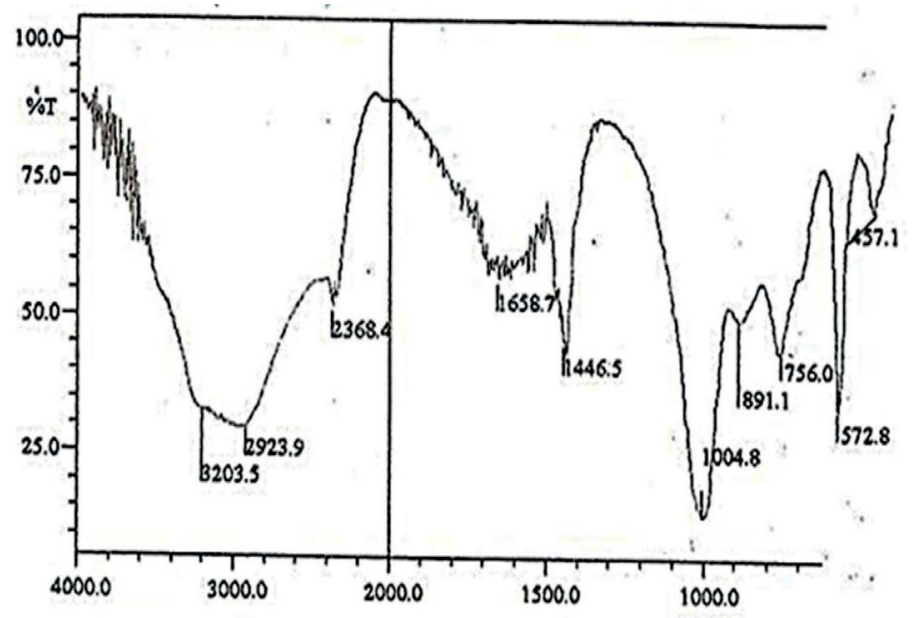

Fig. 4. IR spectrum of struvite crystal. 
Table 2. Crystal data and structure refinement.

\begin{tabular}{|c|c|}
\hline Empirical formula & H4 Mg0.25 N0.25 O2.50 P0.25 \\
\hline Formula weight & 61.35 \\
\hline Temperature & $293(2) \mathrm{K}$ \\
\hline Wavelength & $0.71073 \mathrm{~A}$ \\
\hline Crystal system, space group & Orthorhombic, Pmn21 \\
\hline Unit cell dimensions & $\begin{array}{l}a=6.9447(4) \text { A } \quad \text { alpha }=90 \mathrm{deg} . \\
b=6.1329(4) A \quad \text { beta }=90 \mathrm{deg} . \\
c=11.2026(7) \text { A } \quad \text { gamma }=90 \mathrm{deg} .\end{array}$ \\
\hline Volume & $477.13(5) A^{\wedge} 3$ \\
\hline Z, Calculated density & $8,1.708 \mathrm{Mg} / \mathrm{m}^{\wedge} 3$ \\
\hline Absorption coefficient & $0.390 \mathrm{~mm}^{\wedge}-1$ \\
\hline$F(000)$ & 260 \\
\hline Crystal size & $0.3 \times 0.2 \times 0.2 \mathrm{~mm}$ \\
\hline Crystal description & Prismatic \\
\hline Crystal color & colorless \\
\hline Theta range for data collection & 3.32 to $28.28 \mathrm{deg}$ \\
\hline Limiting indices & $-9<=h<=9,-8<=k<=8,-14<=\mid<=14$ \\
\hline Reflections collected / unique & $6653 / 1280[\mathrm{R}(\mathrm{int})=0.0241]$ \\
\hline Completeness to theta $=28.28$ & $99.9 \%$ \\
\hline Absorption correction & Semi-empirical from equivalents \\
\hline Max. and min. transmission & 1.0 and 0.9 \\
\hline Refinement method & Full-matrix least-squares on $\mathrm{F}^{\wedge} 2$ \\
\hline Data / restraints / parameters & $1280 / 17 / 106$ \\
\hline Goodness-of-fit on $\mathrm{F}^{\wedge} 2$ & 1.376 \\
\hline Final R factors $[I>2 \sigma(I)]$ & $R_{1}=0.0331, w R_{2}=0.0898$ \\
\hline Final $R$ factors (all data) & $R_{1}=0.0332, w R_{2}=0.0898$ \\
\hline Absolute structure parameter & $0.19(16)$ \\
\hline Largest diff. peak and hole & 0.477 and -0.304 e. $A^{\wedge}-3$ \\
\hline
\end{tabular}

$\mathrm{hkl}$ were $\mathrm{h} \rightarrow-9$ to $+9, \mathrm{k} \rightarrow-8$ to +8 and $\mathrm{I} \rightarrow-14$ to +14 . A total of 6653 reflections were collected and averaged basis on the symmetry equivalents. Unique reflections of 1280 resulted with $R_{\mathrm{int}}=$ 0.024 . The completeness resulted in a maximum value of $99.9 \%$ for the $\theta \rightarrow 28.28^{\circ}$. The structure of struvite was solved by direct methods and refined by full-matrix least-squares procedures to a final R-value of $3.31 \%$ and weighted R-value of $8.98 \%$. The crystal structure was solved by using SHELXL97 ${ }^{22}$. The perspective view of the molecule is shown in Fig. 5.

The detailed study on the bond lengths and bond angles of the molecule revealed that the $\mathrm{Mg}$ environment assumes the octahedral arrangement. The neutron diffraction data on the ammonium group revealed three possibilities, namely (i) ammonium group might be either rotating about a fixed axis, (ii) rotating about a randomly oriented axis or (iii) fixed with structure by at least two bonds.
In this study, the ammonium group is fixed by two hydrogen bonds as follows:

N1 - O5: 3.024(3) Aं; 157.7(12) ; N1-02: 2.784(4) $\AA$; $173(4)^{\circ}$

The bonding nature is in extended form. A slight electrostatic imbalance is noted around ammonium $\mathrm{N}$ atom, but the features around the atom fulfill the conditions. The packing of the molecules indicates the well-formed hydrogen bonding for the ammonium group and the $\mathrm{O}$ atoms associated with $\mathrm{Mg}$. Also, $\mathrm{N}-\mathrm{H}$...O and O-H...O types of hydrogen bondings lead to the network in the unit cell.

Struvite crystallizes in the orthorhombic system with cell dimensions $a=6.9447 \AA, b=6.1329$ $\AA, c=11.2026 \AA$. The space group is $P m n 2_{1}$, and there are two molecules in the unit cell. The structure of struvite crystals consists of regular $\mathrm{PO}_{4}{ }^{3-}$ tetrahedra, distorted $\mathrm{Mg} \cdot 6 \mathrm{H}_{2} \mathrm{O}$ octahedra, $\mathrm{NH}_{4}^{+}$groups, which are held together by hydrogen 

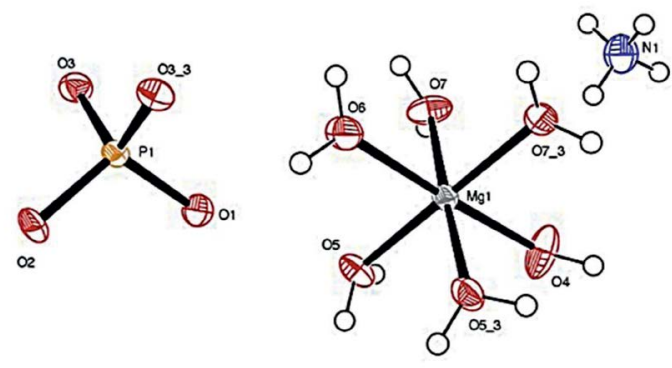

Fig. 5. Atomic coordination of struvite produced by $E$. aestuarii St. SR 101.

bonding. The structure of struvite crystals in the present study was in good agreement with that reported previously 9,23 .

Yang and Sun suggested that phosphate metabolism or phosphate containing organic compounds could be a good source for inorganic phosphate ${ }^{24}$. Ben Omar et al..$^{25}$ and GonzalezMunoz et al. ${ }^{26}$ conducted a series of experiments on struvite formation with several soils inhabiting genera, like Azotobacter, Bacillus, Myxococcus, and Pseudomonas. In earlier research findings by Ben Omar et al. revealed that the struvite precipitation would not occur until the autolysis of Myxococcus xanthus cultures and the actual physical presence of the bacteria was necessary ${ }^{27}$. Ben Omar et al. also found that dead cells, disrupted cells, and membrane fractions of this microorganism induce the struvite crystallization ${ }^{2}$. All the reports lend support to this present biomineralization process of struvite.

In Environmental mineralogy, the precipitation of struvite from sewage has been a subject of considerable investigations because it may offer a potential route for dephosphorization of wastewater from industries and recover phosphates for recycling in the form of fertilizer. Struvite has many potential uses as a fertilizer. The most promising application is as a slow-release fertilizer that can be applied in a single high dose without damage to growing plants since this might have low leach rates and thus slowly releases nutrients in the given environment. At present, numerous research projects are focusing on the controlled precipitation of struvite and its later utilization as a fertilizer ${ }^{28,29,30}$. A better understanding of its formation process, especially in terms of the degree of biological controlled vs. biologically induced mineralization, will undoubtedly provide the additional knowledge in this regard and facilitate future work on biomineralization of struvite-type phosphate minerals ${ }^{31,32}$.

The present study is the first report on biomineralization of struvite by an agarolytic bacterium since biomineralization occurs in viable biomass and this study elucidated the association of biomineralization with physio-logical traits of the bacterium which indicates the present struvite shall be a potentially useful Bioresource.

\section{ACKNOWLEDGMENTS}

Authors are thankful to Dr. Babu Varghese Ph. D, Head, Sophisticated Analytical Instrument Facility, Indian Institute of Technology Madras, Chennai, India for providing Instrumentation facilities and valuable suggestions.

\section{CONFLICTS OF INTEREST}

The authors declare that there are no conflicts of interest.

\section{AUTHORS' CONTRIBUTION}

All authors have made substantial, direct and intellectual contribution to the work and approved it for publication.

\section{FUNDING}

None.

\section{DATA AVAILABILITY}

All datasets generated or analyzed during this study are included in the manuscript and/or the Supplementary Files.

\section{ETHICS STATEMENT}

Ethical clearance was obtained from Institutional Ethical Committee

\section{REFERENCES}

1. Ferris F.G. In Riding R.E., Awramik S.M., (eds.), Microbe metal interaction in sediments, Springer-Verlag, Berlin, Microbial Sediments, 2000. pp. 121-126..

2. Ben Omar N., Gonzalez-Munoz M.T., Penalver J.M.A. Struvite crystallization on Myxococcus cells. Chemosphere, 1998; 36: 475-481.

3. Vasanthi L.A., Muruganandam A., Revathi P., Baskar B., Jayapriyan K., Baburajendran R., Munuswamy N. The application of histo-cytopathological biomarkers in the mud crab Scylla serrata (Forskal) to assess heavy 
metal toxicity in Pulicat Lake, Chennai. Mar. Pollut. Bull., 2014; 81(1): 85-93.

4. Balakrishnan B., Sahu B.K., Ranishree J.K., Lourduraj A.V., Nithyanandam M., Packiriswamy N., Panchatcharam P. Assessment of heavy metal concentrations and associated resistant bacterial communities in bulk and rhizosphere soil of Avicennia marina of Pichavaram mangrove, India. Environ. Earth Sci., 2017; 76(1): 58.

5. Lowenstam H.A., Weiner S. Biomineralization, p. 324. Oxford University Press, New York, 1989.

6. Baskar B., Prabakaran P. Isolation and characterization of copper resistant Exiguo-bacterium strains isolated from rhizosphere soil of Avicennia marina. Res. J. Pharm. Biol. Chem. Sci., 2011; 2(4): 640-646.

7. Baskar B., Prabakaran P. Assessment of nitrogen fixing bacterial community present in the rhizosphere of Avicennia marina. Indian J. Geo-Mar. Sci., 2015; 44(3): 318-322.

8. Robinson $\mathrm{H}$. On the formation of struvite by microorganisms. Proc. Camb. Phil. Soc., 1889; 6; 360-362.

9. Whitaker A., Jeffery J.W. The crystal structure of struvite, $\mathrm{MgNH}_{4} \mathrm{PO}_{4} \cdot 6 \mathrm{H}_{2} \mathrm{O}$. Acta Cryst B, 1970; 26: 1429-1438.

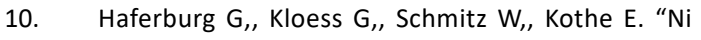
-struvite" - a new biomineral formed by a nickel resistant Streptomyces acidiscabies. Chemosphere, 2008; 72: 517- 523.

11. Chen L., Shen Y., Xie A., Hang F., Zhang W., Liu S. Seedmediated synthesis of unusual struvite hierarchical superstructures using bacterium. Cryst. Grow Design, 2010; 10: 2073-2082.

12. Yang H., Sun H.J., Downs R.T. Hazenite, $\mathrm{KNaMg}_{2}\left(\mathrm{PO}_{4}\right)_{2} \cdot 14 \mathrm{H}_{2} \mathrm{O}$, a new biologically phosphate mineral, from Mono Lake, California, U.S.A. Americ. Mineralo., 2011; 96: 675-681.

13. Balakrishnan B., Ranishree J.K., Thadikamala S., Panchatcharam P: Purification, characterization and production optimization of a vibriocin produced by mangrove associated Vibrio parahaemolyticus. Asian Pac. J. Trop. Biomed., 2014; 4(4): 253-261.

14. Rivadeneyra M.A., Parraga J., Delgado R., RamosCormenzana A., Delgado G. Biomineralization of carbonates by Halobacillus trueperi in solid and liquid media with different salinities. FEMS Microbial. Ecol., 2004; 48: 39-46.

15. Ferrer M.R., Quevedo-Ssrmiento J., Bejar V., Delgado R., Ramos-Cormenzana A., Rivadeneyra M.A. Calcium Carbonate formation by Delega halophila: effect on salt concentration and incubation temperature. Geomicrobiol J., 1998; 6: 49-57.

16. Ahimou F., Denis F.A., Touhami A., Dufrene Y.F. Probing microbial cell surface charges by atomic force microscopy. Langmuir, 2002; 18: 9937-9941.

17. Lytle D.A., Johnson C.H., Rice E.W. A systematic comparison of the electro kinetic properties of environmentally important microorganism in water. Coll. Surf. B: Biointerfaces, 2002; 24: 91-101.

18. Rivadeneyra M.A., Perez-Gracia I., Ramos-Cormenzana A. Influence of ammonium ion on bacterial struvite production. Geomicrobiol. J., 1992; 10: 125-137.

19. Hirasawa I., Kaneko S., Kanai Y., Hosoya S., Okuyama S., Kamahara T. Crystallization phenomena of magnesium ammonium phosphate (MAP) in a Fluidized-bed-type crystallizer. Cry. Grow., 2002; 237: 2183-2187.

20. Goni A., Pizarro J.L., Lezama L.M., Barberis G.E., Arriortua M.I., Rojo T. Synthesis crystal structure and spectroscopic properties of $\mathrm{NH}_{4} \mathrm{NiPO}_{4} \mathrm{nH}_{2} \mathrm{O}(\mathrm{n01}, 6)$ compounds. J. Mater. Chem., 1996; 6: 421-427.

21. Banks E., Chianelli R., Korenstein K. Crystal chemistry of struvite analogs of the type MgMPO4. ${ }_{6 \mathrm{H} 2 \mathrm{O}}\left(\mathrm{M}^{+}=\mathrm{K}+\right.$, $\mathrm{Rb}^{+}, \mathrm{Cs}^{+}, \mathrm{Tl}^{+}, \mathrm{NH}_{4}^{+}$). Inorg Chem, 1975; 14: 1634 -1639.

22. Sheldrick G.M. A short history of SHELX. Acta Crystal, 2008; 64: 112-122.

23. Abbona F., Calleri M., Ivaldi G. Synthetic struvite, $\mathrm{MgNH}_{4} \cdot 6 \mathrm{H}_{2} \mathrm{O}$ : correct polarity and surface features of some complementary forms. Acta Cryst B, 1984; 40: 223-227.

24. Yang H.X., Sun H.J. Crystal structure of a new phosphate compound, $\mathrm{Mg} 2 \mathrm{KNa}\left(\mathrm{PO}_{4}\right)_{2} 14 \mathrm{H}_{2} \mathrm{O}$. J Solid State Chem., 2004; 177: 2991-2997.

25. Ben Omar N., Matinez-Canamero M., Gonzalez-Munoz M.T., Arias J.M., Huetas F. Myxococcus xanthus killed cells as inducers of struvite crystallization; Its possible role in the bio-mineralization processes. Chemosphere, 1995; 30: 2387-2396.

26. Gonzalez-Munoz M.T., Ben Omar N., MartinezCanamero M., Rodriguez-Gallego M., Lopez-Galindo A., Arias J.M. Struvite and Calcite crystallization induced by cellular membranes of Myxococcus xanthus. J. Cry. Gro., 1996; 163: 434-439.

27. Ben Omar N., Entrena M., Gonzalez-Munoz M.T., Arias J.M., Huetas F. The effects of $\mathrm{pH}$ and phosphate on the production of struvite by Myxococcus xanthus. Geomicrobiol. J., 1994; 12: 81-90.

28. Shu L., Schneider P., Jegatheesan V., Johnson J. An economic evaluation of phosphorous recovery as struvite from digester supernatant. Biores. Technol., 2006; 97: 2211-2216.

29. Machnicha A., Grubel K., Suschka J. Enhanced biological phosphorous removal and recovery. Wat. Enviro. Res., 2008; 80: 617-623.

30. Forrest A.L., Fattah K.P., Mavinic D.S., Koch F.A. Optimizing struvite production for phosphate recovery in WWTP. J Enviro Eng, 2008; 134: 395-402.

31. Lowenstam H.A. Minerals formed by organisms. Science, 1981; 211: 1126-1131.

32. Mann S. Mineralization in biological systems. Struct. Bond, 1983; 54: 125-174. 